\title{
TANÍTÓJELÖLTEK OLVASÁSSAL KAPCSOLATOS NÉZETEI
}

\section{TóTH BEATRIX}

az Eötvös Loránd Tudományegyetem Tanító- és Óvóképző Főiskolai Karának

föiskolai docense

tothbeat@kincsem.tofk.elte.hu

A cikkben bemutatott kutatás új témát emel be a pedagógusjelöltek gondolkodásának, illetve nézeteinek vizsgálatába. A szerzö zárt kérdöív felhasználásával tárta fel elsőéves tanitó szakos hallgatók olvasással kapcsolatos elképzeléseit, arra keresve a választ, hogy azok a tradicionális készségközpontú felfogáshoz állnak-e közelebb, avagy a kognitiv-konstruktív olvasáskoncepcióhoz. Az eredmények azt mutatták, hogy a hallgatók elözetes nézetei jellemzöen eklektikusak, ugyanakkor nyitottabbak a konstruktív olvasásfelfogás iránt.

\section{A belépő nézetek vizsgálatának jelentősége a pedagógusképzésben}

A pedagógusjelöltek belépő nézeteinek vizsgálata napjainkban világszerte dinamikusan fejlődő, kiszélesedő kutatási terület. Hátterében a kognitív pszichológia, a konstruktív tanuláselmélet, valamint a reflektív pedagógiai szemlélet és gyakorlat térhódítása áll (Szivák, 2002; Falus, 2006). Jelentőségét az adja, hogy - amint azt a külföldi vizsgálatok meggyőzően bizonyították - a hallgatók előzetes élményei, tapasztalatai, elképzelései, naiv elméletei szürőként funkcionálnak a pályára való felkészítés folyamatában; meghatározzák, hogy hogyan viszonyulnak a képzés tartalmaihoz, mit sajátítanak el és mit nem, s végső soron gyakorlati pedagógiai tevékenységükre is döntő hatással bírnak (Falus, 2001; Szivák, 2002; Dudás, 2005). Ezért is tekinti Falus a pedagógusképzés megújításában kulcstényezőnek a belépő nézetek feltárását és felhasználását (Falus, 2006).

A téma hazai szakirodalmában tájékozódva azt tapasztaltam, hogy a hallgatók élményeit, tapasztalatait, elképzeléseit, nézeteit mindezidáig elsősorban a nevelés alapvető tényezőivel, kategóriáival kapcsolatban vizsgálták a kutatók (Golnhofer és M. Nádasi, 1981: nevelési célok; M. Nádasi, 1999: nevelési célok, tanulókép; Oroszné, 2002: saját élményủ nevelői minta; Szivák, 2003: nevelés, tanítás, tanulás, tanár- és tanulókép; Hunyady, 2004: nevelés, oktatás, a tananyagtudás forrásai, tervezés, gyerektípusok, „rossz gyerek”; Dudás, 2006: tanár, diák, tanulás, tanítás, tanári szerep; Hunyady, M. Nádasi és Serfözö, 2006: „fekete pedagógia”), az olvasással, olvasástanítással összefüggésben nem. Külföldön viszont évtizedek óta folynak kutatások ezen a területen is mind a pedagógusok, mind a pedagógusjelöltek körében (például: Hollingsworth, 1989; Richardson et al., 1991; Lonberger, 
1992; Wham, 1993; Nierstheimer et al., 1996, 2000). Hollingsworth egy olyan longitudinális vizsgálat első évéről számol be, melynek keretében öt éven át kísérték figyelemmel pedagógushallgatók olvasástanítással kapcsolatos elképzeléseinek, tudásának alakulását. A legfontosabb kutatások és kutatási témák Kara-Soteriou (2007) szerint a következők: a nézetek és a gyakorlati tevékenység kapcsolata; tanárok saját olvasástanítási gyakorlatukra vonatkozó nézetei; az olvasás-, írástudással kapcsolatos elméletek, teóriák; az olvasók olvasással kapcsolatos nézetei; valamint az olvasott szövegekkel összefüggő elképzelések.

Az Egyesült Államokban mind a hallgatók előzetes elképzeléseinek feltárása, mind e nézetek létezésének tudatosítása - s ezt követően a hiteknek, meggyőződéseknek a tudományosan, kutatásokkal megalapozott tudással való konfrontálása része a pályára való felkészítésnek. Több egyetemi honlapon találtam erre utaló információkat. Az egyik olvasásmódszertani programban például az olvasható (Woods, 2003), hogy a kurzus megkezdésekor a hallgatóknak esszét kell írniuk és egy kérdőívet kitölteniük az olvasással, olvasástanulással, illetve saját olvasási gyakorlatukkal kapcsolatban. Az egyik jegyzetként használt olvasásmetodikai tankönyv az első fejezetben tárgyalja az olvasással kapcsolatos elképzelések jelentőségét, szerepét az olvasástanításban (Vacca et al., 2006). A fejezet feldolgozásának eredményeként a szerzők reményei szerint a hallgatók képesek lesznek megmagyarázni, hogyan hatnak az írásbeli nyelvhasználat tanulásával kapcsolatos nézetek a tanítási döntésekre, az osztálytermi gyakorlatra, valamint képesek lesznek azonosítani azokat a személyes a tapasztalataikat, amelyek befolyásolják az olvasás-írás tanulásával kapcsolatok nézeteiket.

$\mathrm{Az}$ anyanyelvi tantárgy-pedagógia oktatójaként magam is fontosnak tartom, hogy tájékozódjam leendő tanítványaim olvasással, olvasástanulással és -tanítással kapcsolatos előzetes élményeiről, tapasztalatairól, nézeteiről, elképzeléseiről, hiszen ezek ismerete segíti a tantárgy-pedagógia kurzus megtervezését: a kívánatos tartalmak, arányok és hangsúlyok kialakítását éppúgy, mint a legcélravezetőbb módszerek megválasztását.

\section{A kutatás elméleti háttere: az olvasás fogalmának átalakulása}

Az elmúlt évtizedekben jelentősen átalakult az olvasás fogalmának pedagógiai értelmezése, az olvasási folyamat tartalmáról, jellegéröl vallott felfogás, miközben legfontosabb konstituáló eleme változatlanul az olvasottak megértése, a szövegértés maradt. Az olvasáskutatásban hosszú ideig a behaviourista koncepció dominált. E szerint az olvasás egyfajta dekódolás, amelynek során gondolattá és/vagy hangzó nyelvvé alakítjuk a vizuálisan kódolt információkat, azaz reprodukáljuk a jelentést. A megértés folyamatát a szöveg vezérli, az olvasó passzív befogadó. Ebben a koncepcióban az olvasás készségként tételeződik: a megértés sikerének kulcsa a dekódolás begyakorlottsága, hibátlan volta. 
Az olvasás kognitív-konstruktív felfogása szerint viszont az olvasó nem egyszerúen megérti, hanem aktívan teremti, létrehozza a jelentést, mégpedig meglévő tudása, tapasztalatai bázisán; vagyis a jelentés szöveg és olvasó együttmüködésének, interakciójának eredménye (Iser, 1996), az egyéni olvasatok pedig személyes konstrukciók. A jelentésteremtés folyamatában az olvasó hipotéziseket, jóslatokat fogalmaz meg a szöveg várható folytatásával kapcsolatban, következtetéseket von le, ideiglenes jelentéseket tételez, nyomon követi azok érvényességét, szükség esetén korrigál, elhárítja a megértés akadályait (például megpróbálja kitalálni egy ismeretlen szó jelentését a kontextusból), vagyis problémákat old meg. Az olvasás kognitív szemléletü felfogásában tehát a megértés aktív és produktív folyamat, amelyben kitüntetett szerepe van az olvasó meglévő tudásrendszerének, világismeretének és szociokulturális hátterének. Mindez a kilencvenes évek derekán kiegészült a motiváció szempontjával, ami azt jelenti, hogy jeles kutatók az olvasás-szövegértés lényeges komponenseként határozzák meg az egyén olvasással kapcsolatos motivációs bázisát, az olvasás iránti elkötelezettségét (Cs. Czachesz, 1999, 2005).

A nemzetközi vizsgálatok jó ideje a kognitív-konstruktivista felfogásra épülnek, és a megértés mellett hangsúlyozzák az olvasottak felhasználásának, reflektálásának, értékelésének jelentőségét is (Csapó, 2003). A PIRLS olvasási-szövegértési vizsgálat kidolgozói „,...az olvasást konstruktív és interaktív folyamatnak, az olvasókat pedig aktív értelmezőknek tekintik, akik ismerik és alkalmazzák az aktív olvasás stratégiáit, és képesek reflektálni az olvasott szövegre. Pozitív attitüdöt mutatnak az olvasás iránt, és kedvtelésből, illetve információszerzés céljából egyaránt olvasnak." (Vári, et al., 2003, 119. o.) E definíció az olvasásvizsgálatok történetében elöször említi meg az aktív olvasás stratégiáinak használatát az olvasás folyamatában.

Stratégián az olvasás és a szövegértés-tanítás szakirodalmában többféle dolgot is értenek: egyrészt különböző olvasási-szövegkezelési módokat (mint például az előzetes áttekintés, beleolvasás, gyors átfutás (lefölözés), kereső olvasás, tanulás, szoros olvasás, javító olvasás, újraolvasás), másrészt azokat a kognitív és metakognitív folyamatokat, melyeket az olvasó a jelentés megteremtése érdekében alkalmaz. Nálunk az olvasási stratégia szakkifejezés - leszámítva a posztmodern irodalomelméleti diskurzusokat - sokáig szinte teljesen ismeretlen volt, jóllehet az angol nyelvterületen évtizedek óta kiemelten fontos kutatási és publikációs téma.

A nyolcvanas években elkezdték módszeresen feltárni a jó olvasók olvasási stratégiáit. Harvey és Goudvis (2000) összefoglalása szerint ezek a következők. A jó olvasó

- kapcsolatot keres a meglévő tudása és a szöveg új információi között, aktivizálja és felhasználja a témával kapcsolatos háttértudását az olvasás előtt, alatt és után;

- azonosítja a szöveg legfontosabb témáit, gondolatait vagy esztétikai hatáselemeit, azaz meghatározza a relevanciákat, kiemeli a lényeget; 
- kérdéseket tesz fel a homályos pontok tisztázására, az olvasás fókuszálására, a szerző céljának, nézőpontjának, illetve álláspontjának kiderítésére, $\mathrm{s}$ válaszol is rájuk;

- érzékletes belső képeket alkot a szövegbeli szereplökröl, eseményekröl, helyekről, helyzetekről, tárgyakról, folyamatokról;

- következtetéseket von le előzetes tudása, sémái és a szöveg információi segítségével, ítéleteket, jóslatokat, új gondolatokat fogalmaz meg;

- olvasás közben és a végén összefoglalja, azaz kiemeli és egyúttal saját nyelvén újrafogalmazza, újraalkotja a szöveg legfontosabb gondolatait;

- ha a jelentésteremtés folyamatában valamilyen akadály merül fel, különböző javító stratégiákat használ a probléma megoldására (például újraolvassa az adott részt);

- metakognitív kontrollt gyakorol saját olvasása fölött, azaz nyomon követi megértési folyamatait, tudatában van annak, hogy érti vagy nem, amit éppen olvas.

Más források további stratégiákat is felsorolnak, mint például a szöveg szerkezetének feltárása, mnemotechnikai eljárások alkalmazása vagy grafikus szervezők használata, azaz a fö fogalmak, gondolatok közötti kapcsolatok grafikus megjelenítése (Snow, 2002); illetve a szöveg előzetes áttekintése, az olvasással kapcsolatos célok felállítása, a témával kapcsolatos meglévő tudás aktivizálása, előfeltevések megfogalmazása a várható tartalommal kapcsolatban (Pressley, 2001).

E stratégiák inkább csak elméletben különíthetök el, az olvasás folyamatában gyakran összefonódnak, összekapcsolódnak: a belső képek megalkotása során meglévő tudásunkat, a szöveg bizonyos lényeges elemeit és az olvasás során levont következtetéseinket is felhasználhatjuk. Kibontásuk és azonosításuk azért fontos, hogy tudjuk: miféle összetevőkre, folyamatokra bontható az olvasás-megértés komplex, bonyolult processzusa.

A kilencvenes évektől kezdve elsősorban azt vizsgálták, hogyan taníthatók e stratégiák a gyerekeknek. Mára széles körü konszenzus jött létre a kutatók, szakértők között a tekintetben, hogy a szövegértés színvonalát jelentős mértékben meghatározza, hogy a diákok ismerik-e és alkalmazzák-e a különböző olvasási stratégiákat, képesek-e a céljaiknak leginkább megfelelő stratégiákat kiválasztani és rugalmasan alkalmazni öket olvasás közben (Snow, 2002; Pressley, 2001).

Hazánkban Csíkos Csaba és Steklács János vezetésével folytak az olvasási stratégiák tanításával kapcsolatos kutatások. Eredményeik megerősítették, igazolták a külföldi tapasztalatokat: a stratégiák tanítása jobb teljesítményt eredményezett (Csíkos és Steklács, 2006). 


\section{A kutatás célja, módszere és a minta}

Kutatásom célja az volt, hogy megismerjem a hallgatók tapasztalatait, nézeteit, illetve felfogásukat az olvasással kapcsolatban, valamint elképzelésüket az olvasás taníthatóságára nézve. További célom volt egy olyan kérdőív kipróbálása, melyet - a szükséges finomítások elvégzése után - a későbbiekben is felhasználhatok leendő tanítványaim olvasásfelfogásának megismerésére. A kutatás ekként elővizsgálat jellegü volt. Alapvetően két kutatási probléma vizsgálatára vállalkoztam:

- Mi jellemzi a hallgatók olvasásfelfogását, azaz olvasásfogalmuk a behaviourista vagy a konstruktivista koncepcióhoz áll-e közelebb?

- Milyen jelentőséget tulajdonítanak saját majdani szerepüknek az olvasástanulás eredményessége szempontjából?

A kutatás módszere: írásbeli kikérdezés, zárt kérdőívvel. A saját élmények, tapasztalatok, elképzelések feltérképezésére más módszerek is használhatók (például írásbeli kikérdezés nyitott kérdésekkel, esszé íratása, szóbeli kikérdezés, fogalmi térkép készíttetése), én azonban olyan mérőeszközt kerestem, amelynek alkalmazása viszonylag egyszerü, a kapott eredmények értékelése nem időigényes, mégis elégséges információval szolgál a kutatási kérdések megválaszolásához. Ezt a mérőeszközt Luciano Mariani (1999) egyik publikációjában találtam meg. Az általa összeállított kérdőív segítségével kideríthető, hogy a hallgatók olvasásfogalma, olvasással kapcsolatos elképzelései mifélék: a korszerü kognitív-konstruktív felfogáshoz állnak-e közelebb, vagy inkább a korábbi, mára már meghaladott szemléletet tükrözik. Ennek megfelelően a kérdőív a két különböző olvasáskoncepcióhoz illeszkedő négy-négy kijelentést tartalmaz, kevert elrendezésben. Az ötödik kijelentés az olvasás taníthatóságával kapcsolatos meggyőződés feltárását szolgálja. A választ öt fokú Likert-skálán kellett jelölni. A skála értékeinek jelentése: (1) teljesen egyetért, (2) egyetért, (3) egyet is ért meg nem is, (4) nem ért egyet, (5) egyáltalán nem ért egyet.

A mintavétel módja hozzáférésen alapuló kényelmi stratégia volt, hiszen kutatási céljaim elérését - azaz leendő tanítványaim előzetes nézeteinek részbeni megismerését, valamint a kérdőív kipróbálását - ez is biztosította. Az alapsokaság az ELTE Tanító- és Óvóképző Főiskolai Karának valamennyi elsőéves tanító szakos hallgatója, akik anyanyelvi tantárgy-pedagógiai tanulmányaik megkezdése előtt állnak, összesen 165 fö. A kérdőívet kurzusmailben küldtem el először valamennyi elsőévesnek, majd - mivel jómagam elsőéveseket nem tanítok - néhány kollégámat kértem meg, hogy órájukon osszák a ki a hallgatóknak a kinyomtatott kérdőíveket. Így végül 57 kitöltött kérdőív jutott hozzám vissza, melyeket SPSS-programmal dolgoztam fel. (Mivel néhány hallgató egy-egy kijelentéssel kapcsolatban nem tett jelölést, a minta nagysága változó.) 


\section{A hallgatók olvasásfogalma, olvasással kapcsolatos elképzelései}

A készségközpontú felfogást a következő négy állítás jelenítette meg:

- Az olvasás passzív folyamat: az olvasó befogadja a szöveg tartalmát.

- Az olvasás föleg vizuális tevékenység: a szemünknek fel kell ismernie a betüket, szóról szóra haladva.

- A szöveg megértése megköveteli, hogy az olvasó minden szót ismerjen benne.

- Ha az olvasó nem akarja engedni lankadni a figyelmét, elejétől a végéig folyamatosan kell elolvasnia a szöveget, sorról sorra, megállás nélkül.

A válaszok elemzésének eredményeit az 1. táblázat mutatja.

1. táblázat: A készségközpontú felfogást képviselő kijelentések elfogadottsága (N: 57)

\begin{tabular}{|l|c|c|c|c|c|c|c|}
\hline \multirow{2}{*}{$\begin{array}{c}\text { A kijelentés } \\
\text { tartalma }\end{array}$} & $\begin{array}{c}\mathbf{5} \\
\text { teljesen } \\
\text { egyetért }\end{array}$ & $\begin{array}{c}2 \\
\text { egyetért }\end{array}$ & $\begin{array}{c}3 \\
\text { egyet is } \\
\text { ért meg } \\
\text { nem is }\end{array}$ & $\begin{array}{c}4 \\
\text { nem ért } \\
\text { egyet }\end{array}$ & $\begin{array}{c}5 \\
\text { egyáltalán } \\
\text { nem ért } \\
\text { egyet }\end{array}$ & Átlag & Szórás \\
\hline $\begin{array}{l}\text { Az olvasás } \\
\text { passzív } \\
\text { folyamat }\end{array}$ & 2 & 12 & 24 & 16 & 3 & 3,11 & 0,920 \\
\hline $\begin{array}{l}\text { Főleg vizuális } \\
\text { tevékenység }\end{array}$ & 3 & 18 & 17 & 15 & 4 & 2,98 & 1,044 \\
\hline $\begin{array}{l}\text { Minden szót } \\
\text { ismerni kell }\end{array}$ & 4 & 17 & 13 & 19 & 4 & 3,04 & 1,101 \\
\hline $\begin{array}{l}\text { Folyamatosan } \\
\text { kell olvasni }\end{array}$ & 1 & 10 & 18 & 20 & 8 & 3,42 & 0,999 \\
\hline & & & & & & 3,14 & \\
\hline
\end{tabular}

Az eredmények értelmezése során általában három csoportba soroltam a válaszokat aszerint, hogy egyetértést, elutasítást vagy bizonytalanságot fejeznek ki. Úgy látszik, még ma is elég sokan vallják a tradicionális felfogást, mely szerint az olvasás passzív befogadás, hiszen az első kijelentés tartalmával a hallgatók 24,6\%-a - akik az 1-es vagy a 2-es értéket választották - egyetért. Ez alighanem abból az olvasói tapasztalatból származik, hogy sok esetben minden különösebb intellektuális erőfeszítés nélkül olvasunk, mintegy alapjáraton müködtetve olvasási képességünket. Ha ugyanis a szöveg nem tartalmaz ismeretlen szót, fogalmat, szokatlan nyelvi szerkezetet, új információt, az olvasás könnyünek tünik, a jelentésteremtés automatikus, 
problémamentes; így a kogníció, az aktív információfeldolgozás elfedett, szinte észrevétlen. Egy másik lehetséges ok, hogy az olvasásfelfogás megváltozása a szaktudományban nem egy csapásra formálja át a gyakorlatot és a benne müködő pedagógusok gondolkodását. Ráadásul az új, konstruktivista koncepcióra épülő gyakorlat újfajta megközelítéseket, tanítási módszereket, technikákat igényel. Ezek elterjesztése sem megy egyik napról a másikra. Valószínủ tehát, hogy hallgatóink jó része még a hagyományos olvasásfelfogáson alapuló tanítási folyamatban szocializálódott. Ehhez képest biztató, hogy egyharmaduk $(33,4 \%)$ nem ért egyet az állítással (vagyis a 4-es és az 5-ös értéket választotta), 42,1\%-a pedig egyet is ért meg nem is. Alighanem volt már olyan olvasói élményük, amelynek során megtapasztalták, hogy olykor bizony aktívan meg kell küzdeniük a jelentésért. A 3,11-es átlag is azt mutatja, hogy a többség nem értett egyet ezzel az indikátor kijelentéssel.

A második kijelentés lett a legelfogadottabb. A hallgatók 31,6 százaléka egyet ért azzal, hogy az olvasás föleg vizuális tevékenység. Ez egyrészt abból adódhat, hogy vizuális észlelés hiján valóban nem beszélhetünk szorosan vett olvasásról, de joggal merül fel az a magyarázat is, hogy az olvasást vizuális jelek dekódolásának tekintik, a megértést pedig a dekódolás automatikusan megszülető eredményének. Vagyis az olvasás folyamatában nagyobb jelentőséget tulajdonítanak a percepciónak és kisebbet a kogníciónak.

A harmadik kijelentés osztotta meg leginkább a válaszolókat. Jól jelzi ezt, hogy e tételnél legnagyobb a szórás. Az előzőekhez képest kisebb volt a 3-ast választó bizonytalanok aránya $(22,8 \%)$, az egyértelmüen állást foglalókon belül valamivel többen fejezték ki egyet nem értésüket, mint egyetértésüket. Ez utóbbiak száma mindenképpen magasnak tünik, és jelzi, hogy sokak olvasói gyakorlatából hiányzik az a tapasztalat, hogy az ismeretlen szavak jelentését gyakran ki lehet következtetni a kontextusból grammatikai, szintaktikai vagy éppen pragmatikai kulcsok segítségével. Bár az is meglehet, hogy - tévesen - a gyerekeket nem tartják képesnek erre.

A negyedik kijelentést utasították el a legtöbben. Ám még így is a hallgatók 19,3\%-a választotta az 1-es és a 2-es értéket, igaz, döntő többségük az utóbbit. Ök tehát egyetértenek azzal, hogy a szövegek olvasásában folyamatosan elöre kell haladni, jóllehet az olvasáskutatás hajnalán kibontakozó szemmozgás-kutatások már nagyon korán felfedezték, hogy a szakkadikus ugrások nem csak elöre irányulnak, előfordul regresszió is, föleg ha nehéz a szöveg és problémák merülnek fel a megértésben. Igaz, az is kiderült, hogy bár vannak szándékos visszaugrások is, többségük mégsem tudatos (Cs. Czachesz, 1998).

A konstruktivista olvasásfelfogást az alábbi állítások reprezentálták:

- A szövegek olvasásának nem csak egyetlen módja van: különböző olvasási módok vannak, a körülményektől függően.

- Az olvasás módjáról az olvasó dönt annak alapján, hogy milyen típusú szövegről van szó, ill. hogy mi az olvasás célja.

- A szöveg megértése az olvasó előzetes tudásán múlik. 
- Az olvasó elöre választhat stratégiát a szöveg olvasásához, és kontrollálhatja a stratégia használatát, amíg olvas.

Az állítások elfogadottságával kapcsolatos eredményeket a 2. táblázat mutatja. (Mivel egy-egy kijelentés esetében hárman nem jelöltek meg értéket, az elemszám változó.)

2. táblázat: A konstruktivista felfogást képviselő kijelentések elfogadottsága

\begin{tabular}{|l|c|c|c|c|c|c|c|}
\hline \multirow{2}{*}{$\begin{array}{c}\text { A kijelentés } \\
\text { tartalma, } \\
\text { a válaszolók } \\
\text { száma }\end{array}$} & $\begin{array}{c}1 \\
\text { teljesen } \\
\text { egyetért }\end{array}$ & $\begin{array}{c}2 \\
\text { egyetért }\end{array}$ & $\begin{array}{c}3 \\
\text { egyet is } \\
\text { ért meg } \\
\text { nem is }\end{array}$ & $\begin{array}{c}4 \\
\text { nem ért } \\
\text { egyet }\end{array}$ & $\begin{array}{c}5 \\
\text { egyáltalán } \\
\text { nem ért } \\
\text { egyet }\end{array}$ & Atlag & Szórás \\
\hline $\begin{array}{l}\text { Különböző } \\
\text { olvasási módok } \\
\text { vannak } \\
\text { (N: 56) }\end{array}$ & 17 & 27 & 9 & 2 & 1 & 1,98 & 0,884 \\
\hline $\begin{array}{l}\text { Az olvasás } \\
\text { módjáról az } \\
\text { olvasó dönt } \\
\text { (N: 55) }\end{array}$ & 18 & 22 & 13 & 2 & - & 1,98 & 0,850 \\
\hline $\begin{array}{l}\text { A megértés az } \\
\text { elözetes } \\
\text { tudáson múlik } \\
\text { (N: 57) }\end{array}$ & 6 & 17 & 24 & 7 & 3 & 2,72 & 0,996 \\
\hline $\begin{array}{l}\text { Az olvasó } \\
\text { alkalmazhat } \\
\text { stratégiákat } \\
\text { (N: 57) }\end{array}$ & 1 & 19 & 27 & 6 & 4 & 2,88 & 0.888 \\
\hline & & & & & & & \\
\hline
\end{tabular}

Első ránézésre megállapítható, hogy a konstruktivista felfogást tükröző kijelentések elfogadottsága nagyobb arányú, mint a tradicionális koncepciót tükrözőké. A hallgatók túlnyomó többsége egyetért vagy legalább részben egyetért azzal, hogy különböző olvasási módok léteznek, és ezek megválasztásáról az olvasó dönthet (3., 4. kijelentés). Saját olvasói gyakorlatában ki-ki bőséggel szerezhetett tapasztalatokat arra nézve, hogy az olvasás különbözö tényezői (pl. az olvasás célja, a szöveg müfaja, a rendelkezésre álló idő stb.) hogyan befolyásolják az olvasás folyamatát. Inkább az a meglepő, hogy volt egyáltalán néhány válaszoló, aki nem 
értett egyet az állításokkal. Jellemzően a szórások e két kijelentés esetében a legalacsonyabbak.

A két másik állítás is inkább elfogadott, mint nem, ám velük kapcsolatban egyfajta bizonytalanság is érzékelhetö; ezt mutatja az „egyet is értek meg nem is” lehetőséget választók magas aránya $(42,1 \%$, ill. $47,4 \%)$. A hallgatók $17,6 \%$-a nem tekinti az előzetes tudást a megértés sikerességét meghatározó tényezőnek. Pedig régi felismerés, hogy minél többet tud valaki egy bizonyos témáról, annál jobban érti az adott tárggyal kapcsolatos szövegeket. Pressley (1999) szerint az olvasó sokféleképpen felhasználja tudását olvasás közben, pl. a várható tartalom elővételezésekor, jóslatainak ellenőrzése során, a szöveg tartalmi elemeinek elfogadásakor vagy elutasításakor, valamint egyéni értelmezésének, olvasatának létrehozásában. A hallgatók egy része viszont nem látja elég világosan a meglévő tudás szerepét, jelentőségét a jelentésteremtés folyamatában. Ám az is lehet, hogy az eredeti mondatban szereplő „depends on” kifejezés fordítása sikerült túlságosan sarkosra. Lehet, hogy ha nem a „múlik”, hanem a „,ügg” ige szerepel a mondatban, nagyobb arányú lett volna az egyértelmú elfogadás.

A stratégiák tudatos, kontrollált használatára vonatkozó megállapítással a hallgatók 17,5 százaléka nem értett egyet, a többség azonban részben vagy egészben egyet értett. Ez nyilván összefügg azon kijelentés magas arányú elfogadottságával, amelynek lényege, hogy az olvasás módjáról az olvasó dönt. Valószínű, hogy a válaszolók jó része ekként értelmezte a stratégia szót. A 3-as értéket választó bizonytalanok nagy arányában pedig alighanem a szójelentés-ismeret hiánya mutatkozik meg.

Összességében elmondható, hogy a hallgatókhoz közelebb áll a konstruktivista olvasásfelfogás, mint a hagyományos készségközpontú koncepció. Ezt tanúsítják az egyes kijelentések átlagai és az összesített átlagok is: a konstruktivista koncepciót képviselő állítások átlaga 2,39; a készségközpontú felfogást leíróké 3,14.

Az 1. és 2. ábra azt szemlélteti, hogy hogyan oszlanak meg a hallgatók által megjelölt összesített értékek a két különböző olvasásfelfogást reprezentáló kijelentésekkel kapcsolatban. A vízszintes tengely azt mutatja, hogy mennyi az összesített érték, a függőleges pedig, hogy hány hallgató jelölt éppen annyit. 


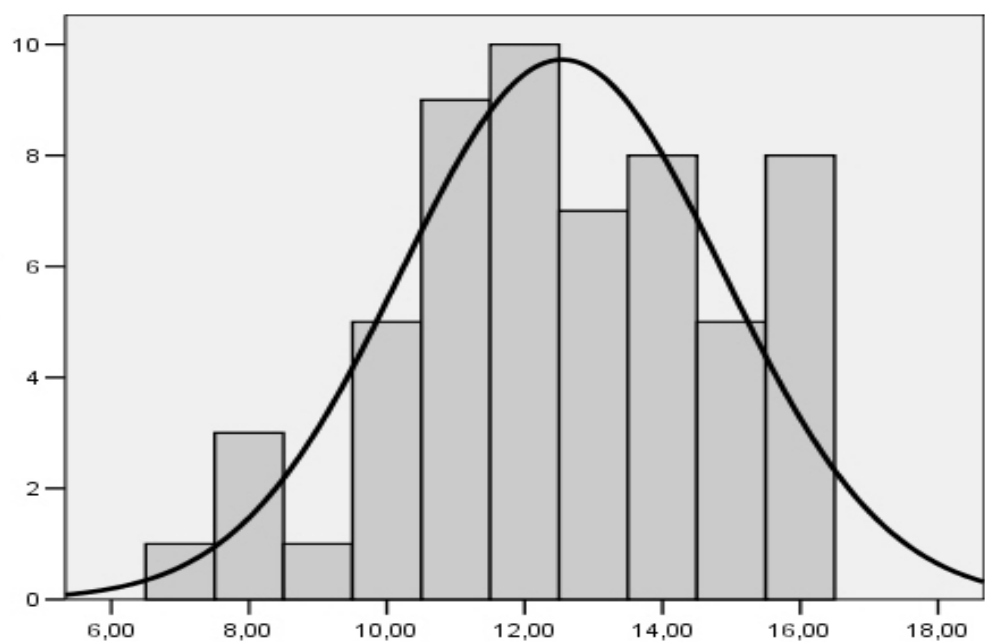

1. ábra: A készségközpontú indikátor kijelentések összértékének gyakorisági megoszlása $(\mathrm{N}=54)$

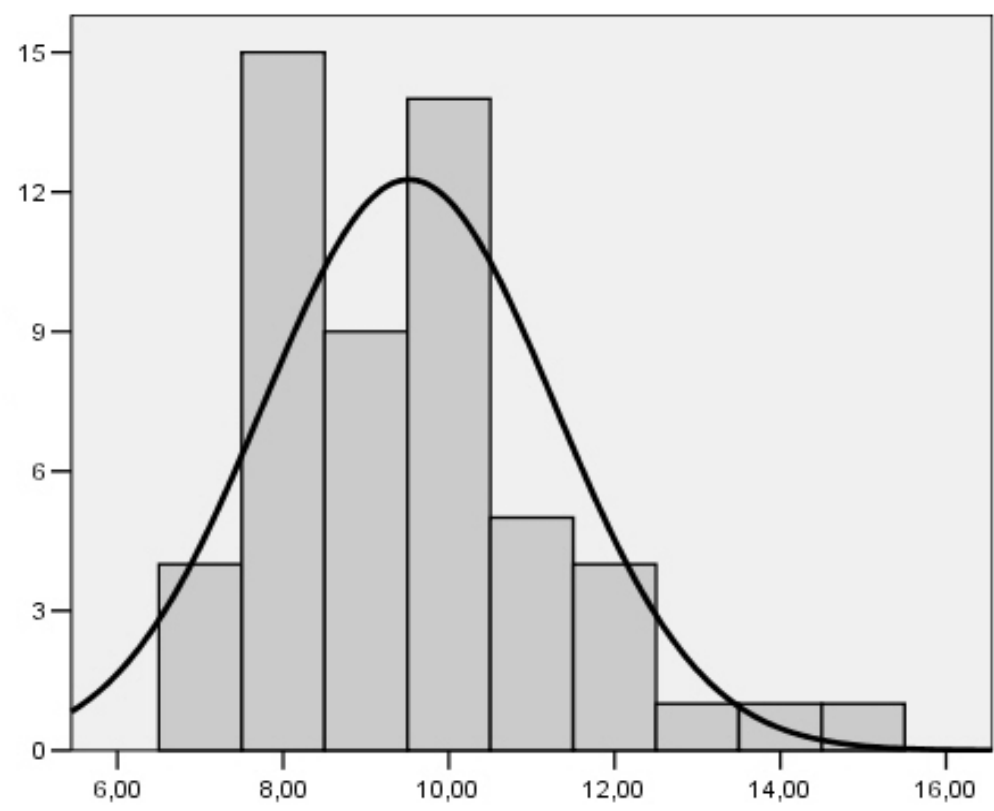

2. ábra: A konstruktivista indikátor kijelentések összértékének gyakorisági megoszlása $(\mathrm{N}=54)$ 
3. táblázat: A különböző olvasáskoncepciók elfogadottsága (N=54)

\begin{tabular}{|l|c|c|c|}
\hline \multicolumn{1}{|c|}{ Olvasásfelfogás } & Egyetért & Bizonytalan & Elutasitja \\
\hline Készségközpontú & 1 & 52 & 1 \\
\hline Konstruktivista & 3 & 51 & 0 \\
\hline
\end{tabular}

A 3. táblázatból kiderül, hogy a túlnyomó többség elképzelései, nézetei ellentmondásosak, eklektikusak, bizonytalanok, ugyanakkor az is kiolvasható az adatokból, hogy a konstruktivista felfogás valamivel elfogadottabb a hallgatók körében. (A bizonytalanok nagy arányában valószínüleg a korábban részletesen taglalt okok - egyes szakszavak viszonylagos ismeretlensége, a fordítással kapcsolatos problémák - is közrejátszanak.)

Jelentősen mások az arányok, ha az alapján csoportosítjuk a hallgatókat, hogy melyik kijelentés-sorozat összesített értéke alacsonyabb. Ez jelzi ugyanis azt, hogy a kettő közül melyik koncepció felé nyitottabbak, melyiket fogadják el inkább. A hallgatók így kialakított csoportjait a 4. táblázat szemlélteti.

4. táblázat: A különböző olvasáskoncepciók iránti nyitottság $(\mathrm{N}=57)$

\begin{tabular}{|l|r|c|}
\hline \multicolumn{1}{|c|}{ Olvasásfelfogás } & Fó & $\%$ \\
\hline A készségközpontú felfogás felé nyitott & 8 & 14 \\
\hline A konstruktivista felfogás felé nyitott & 46 & 80,7 \\
\hline Értékelhetetlen & 3 & 5,3 \\
\hline
\end{tabular}

Ez a csoportosítás is azt mutatja, hogy a hallgatók döntő többsége inkább a konstruktivista felfogást képviselő állitásokkal értett egyet, semmint a készségközpontú koncepciót megjelenítőkkel.

\section{Az adottságok szerepe az olvasásban}

A kérdőíven szereplő egyik kijelentés kapcsán arról kellett elgondolkodniuk a hallgatóknak, hogy milyen jelentőséget tulajdonítanak a veleszületett adottságoknak az olvasási teljesítményben. A következő állítással kapcsolatban kellett állást foglalniuk: Az olvasó teljesítményét alapvetően veleszületett, örökölt adottságai határozzák meg. A kijelentés egyúttal implicit módon a gyerekek, ill. az olvasás taníthatóságára kérdezett rá. A válaszok megoszlását az 5. táblázat mutatja. Az eredmények szerint a hallgatók mindössze 16,4\%-a gondolja meghatározónak az olvasási teljesítményben a veleszületett adottságokat - ök azok, akik 1-est vagy 2-est jelöltek véleményük kifejezésére -, 36,4\% részben, 47,2\% egyértelmüen elutasítja ezt az állítást, vagyis más tényezők hatását tartják döntőnek. 
5. táblázat: A hallgatók álláspontja a veleszületett adottságok jelentőségével kapcsolatban (N: 56)

\begin{tabular}{|c|c|c|c|c|c|c|c|}
\hline \multirow{2}{*}{$\begin{array}{c}\text { A kijelentés } \\
\text { tartalma, } \\
\text { a válaszolók } \\
\text { száma }\end{array}$} & $\begin{array}{c}1 \\
\text { teljesen } \\
\text { egyetért }\end{array}$ & $\begin{array}{c}2 \\
\text { egyetért }\end{array}$ & $\begin{array}{c}3 \\
\text { egyet is } \\
\text { ért meg } \\
\text { nem is }\end{array}$ & $\begin{array}{c}4 \\
\text { nem ért } \\
\text { egyet }\end{array}$ & $\begin{array}{c}5 \\
\text { egyáltalán } \\
\text { nem ért } \\
\text { egyet }\end{array}$ & Átlag & Szórás \\
\hline $\begin{array}{l}\text { Az olvasási } \\
\text { teljesítmény az } \\
\text { adottságokon } \\
\text { múlik }\end{array}$ & 3 & 6 & 20 & 18 & 8 & 3,40 & 1,047 \\
\hline
\end{tabular}

\section{Tanulságok, következtetések}

Az eredmények a minta alacsony száma miatt csak tájékoztató jellegủek, a belölük levonható tanulságok, következtetések érvényessége korlátozott. Egyes kijelentések nem kellően pontos megfogalmazása miatt valószínü, hogy egy újabb vizsgálat részben más eredményekhez, arányokhoz vezetne. Érdemes az indikátor kijelentések tartalmát és fordítását felülvizsgálni, szükség esetén finomítani.

A kérdőívek elemzése révén sikerült választ adni a felvetett kutatási problémákra, illetve kutatási kérdésekre, természetesen a fenti korlátokat figyelembe véve. Az eredmények azt mutatják, hogy a hallgatók többségének az olvasási folyamat, illetve tevékenység jellegével kapcsolatos felfogása inkább a konstruktivista koncepcióhoz áll közel, a felé nyitott; de tartalmaz olyan elemeket is, melyek a tradicionális behaviourista felfogásra jellemzőek. Ebből következően az anyanyelvi tantárgy-pedagógiai stúdiumok keretében az olvasástanítás-olvasásfejlesztés teoretikus megalapozásakor súlyt kell helyezni olyan összefüggések bemutatására, mint például az előzetes tudás vagy a stratégiahasználat szerepe az olvasásértésben; más szemléleti elemeket, elképzeléseket - például a vizualitás és az előzetes szóismeret jelentőségével kapcsolatban - célszerú ütköztetni a szakirodalom vonatkozó megállapításaival, célirányosan szervezett saját tapasztalattal. Jó alapokat jelent a képzés számára az, hogy a mintában szereplő hallgatók közül csak kevesen gondolják úgy, hogy az olvasási teljesítményt alapvetően a gyermekek veleszületett adottságai határozzák meg, a többség tehát hisz a gyerekek taníthatóságában.

A hallgatók olvasással kapcsolatos elképzeléseinek egyaránt vannak megerősítendő, átépítendő és kiépítendő elemei. Fontos, hogy lehetőleg már a kurzus megtervezésekor, indításakor fény derüljön ezekre. Oktatóként az is célom volt, hogy kipróbáljam a Mariani-féle kérdőívet a fókuszba állított belépő nézetek megisme- 
résére. Tapasztalataim arról győztek meg, hogy a kérdőívvel nyert adatok megfelelő áttekintést adnak a hallgatók olvasásfelfogásáról, annak jellemzőiről.

Bár a zárt kérdőívvel való kikérdezés nem tipikus módszer a pedagógusok és pedagógusjelöltek gondolkodásának kutatásában, az adott esetben és céllal mégis jól alkalmazható, hiszen könnyen kezelhető, sem a kitöltése, sem az eredmények feldolgozása és értékelése nem túlságosan időigényes. Ugyanakkor kétségtelen, hogy az elözetes tudás, illetve nézetek csak egy szükebb - bár meghatározó jelentôségü - szeletének feltárására alkalmas. A hallgatók olvasással, olvasástanulással kapcsolatos élményeinek, tapasztalatainak feltérképezésére, az olvasás tanításával, a pedagógus szerepével összefüggő elképzeléseik megismerésére más módszerek - szóbeli kikérdezés, esszé íratása stb. - célravezetőbbek. A módszerek kombinálásával pedig nyilvánvalóan teljesebb és strukturáltabb kép alkotható.

\section{Irodalom}

Cs. Czachesz Erzsébet (1998): Olvasás és pedagógia. Mozaik Könyvkiadó, Szeged.

Cs. Czachesz Erzsébet (1999): Olvasástanításunk eredményei és problémái. Modern Nyelvoktatás, 1. sz. 25-35.

Cs. Czachesz Erzsébet (2005): Változó perspektívák az olvasási képesség pedagógiai értelmezésében. Iskolakultúra, 10. sz. 44-52.

Csapó Benő (2003): A tudás és a kompetenciák. In: Monostori Anikó (szerk.): A tanulás fejlesztése. Országos Közoktatási Intézet, Budapest, 65-74.

Csíkos Csaba - Steklács János (2006): Metakogníció és olvasás. In: Józsa Krisztián (szerk.): Az olvasási képesség fejlödése és fejlesztése. Dinasztia Tankönyvkiadó, Budapest, $75-88$.

Dudás Margit (2005): A tanárképzésbe belépő hallgatók nézeteinek feltárási lehetőségei. Pedagógusképzés, 3. sz. 23-43.

Dudás Margit (2006): A belépő nézetek feltárása - bevezetés a „saját pedagógiába”. In: Bárdossy Ildikó - Forray R. Katalin - Kéri Katalin (szerk.): Tananyagok a pedagógia szakos alapképzéshez. PTE BTK Neveléstudományi Intézet, Pécs, [http://nti.btk.pte.hu]

Falus Iván (2001): A gyakorlat pedagógiája. In: Golnhofer Erzsébet - Nahalka István (szerk.): A pedagógusok pedagógiája. Nemzeti Tankönyvkiadó, Budapest, 13-27.

Falus Iván (2006): A tanári tevékenység és a pedagógusképzés új útjai. Gondolat Kiadó, Budapest.

Golnhofer Erzsébet - M. Nádasi Mária (1981): Tanárjelöltek a nevelés céljáról. Magyar Pedagógia, 3. sz. 305-310.

Harvey, S. - Goudvis, A. (2000): Strategies that work. Stenhouse Publishers, York, Maine.

Hollingsworth, S. (1989): Prior Beliefs and Cognitive Change in Learning to Teach. American Educational Research Journal, 2. sz. 160-189. 
Hunyady Györgyné (2004): Laikus pedagógiai tapasztalatok és nézetek vizsgálata a tanítójelöltek körében. In: Bollókné Panyik Ilona (szerk.): Gyermek - nevelés - pedagógusképzés. Trezor Kiadó, Budapest, 9-32.

Hunyady Györgyné - Nádasi Mária - Serfőző Mónika (2006): Fekete pedagógia. Értékelés az iskolában. Argumentum Kiadó, Budapest.

Iser, W. (1996): Az olvasás aktusa. Az esztétikai hatás elmélete. In: Kiss Attila - Kovács Sándor - Odorics Ferenc (szerk.): Testes könyv. I. Ictus Kiadó és JATE Irodalomelméleti Csoport, Szeged, 241-264.

Kara-Soteriou, J. (2007): Exploring students' beliefs about reading. (Report) Academic Exchange Quarterly. Online publication. [http://www.thefreelibrary.com/Exploring+students'+beliefs+about+reading.-a0172686675]

Lonberger, R. B. (1992): The belief systems and instructional choices of preservice teachers. In: Padak, N. D. - Rasinksi, T. V. - Logan, J. (szerk.): Literacy research and practice, foundations for the year 2000. College Reading Association, Pittsburg, 71-78.

Mariani, L. (1999): Probing the hidden curriculum: teachers' and students' beliefs and attitudes. Paper given at the British Council 18th National Conference for Teachers of English. Palermo, 18-20, March 1999. [www.learningpaths.org/papers/paperbeliefs.htm - 91k -]

M. Nádasi Mária (1999): Hétköznapi és/vagy tudományos pedagógia(?!) Tanári létkérdések, 18. kötet, Raabe Kiadó, Budapest.

Nierstheimer, S. L. - Hopkins, C. J. - Dillon, D. R. - Schmitt, M. C. (2000): Preservice teachers' shifting beliefs about struggling literacy learners. Reading Research and Instruction, 1. sz. 1-16.

Nierstheimer, S. L. - Hopkins, C. J. - Schmitt, M. C. (1996): "But I just want to teach regular kids!" Understanding preservice teachers' beliefs about teaching children experiencing difficulty learning to read. Literacy Teaching and Learning, 1. sz. 15-24.

Oroszné Perger Mónika (2002): Jövendő pedagógusok nevelőképe. In: Kovátsné Németh Mária (szerk.): Tanulmánykötet. Nyugat-Magyarországi Egyetem Apáczai Csere János Tanítóképző Főiskolai Kar, Győr, 156-167.

Pressley, M. (1999): Self-regulated comprehension processing and its development through instruction. In: Gambrell, L. B. - L. M. Morrow, L. M. - Neuman, S. B. - Pressley, M. (szerk.): Best practice in literacy instruction. The Guilford Press, New York, 90-97.

Pressley, M. (2001): Comprehension instruction: What make sense now, what might make sense soon. Reading Online, [http:// press.readingonline.org]

Richardson, V. - Anders, P. - Tidwell, D. - Loyd, C. (1991): The relationship between teachers' beliefs and practices in reading comprehension instruction. American Educational Research Journal, 3. sz. 559-586.

Snow, C. (2002): Reading for understanding. Toward an $R \S D$ program in reading comprehension. Rand, Santa Monica. [http://press.rand.org]

Szivák Judit (2002): A pedagógusok gondolkodásának kutatási módszerei. Kutatás-módszertani kiskönyvtár. Müszaki Könyvkiadó, Budapest.

Szivák Judit (2003): Hallgatók neveléssel kapcsolatos nézetei. Iskolakultúra 5. sz. 88-95. 
Vacca, J. L. - Vacca, R. T. - Gove, M. K. - Burkey, L. C. - Lenhart, L. A., - McKeon, C. A. (2006): Reading and learning to read. Pearson Education, Inc., Boston.

Vári Péter - Balázsi Ildikó - Bánfi Ilona - Szabó Annamária - Szabó Vilmos László (2003): Hogyan olvasnak a magyar kilencévesek? Iskolakultúra 8. sz. 118-137.

Wham, M. A. (1993): The relationship between undergraduate course work and beliefs about reading instruction. Journal of Research and Development in Education, 1. sz. 9-17.

Woods, J. (2003): L545. Theme \#1 - Literacy beliefs.

[www.indiana.edu/ lang545/protect/modules/theme1.html - 15k] 